\title{
Effect of exogenous nitrogen and phosphorus inputs on the microbe-soil interaction in the secondary Castanopsis sclerophylla forest in east
}

\section{China}

\author{
Zhen Teng ${ }^{(1)}$, \\ Jun Cui ${ }^{(2)}$, \\ Jingjing Wang ${ }^{(1)}$, \\ Xinlei $\mathrm{Fu}^{(1)}$, \\ Xiaoniu $\mathrm{Xu}^{(1)}$
}

\begin{abstract}
Soil microbes play a key role in the formation and decomposition of organic materials and in the improvement of the ecological environment. Despite continuous increases in nitrogen $(\mathrm{N})$ and phosphorus $(\mathrm{P})$ inputs due to the atmospheric deposition or fertilization, the response of soil to exogenous inorganic nutrients inputs remains elusive. By a manipulative experiment we simulated $\mathrm{N}$ and $\mathrm{P}$ depositions in a subtropical secondary Castanopsis sclerophylla forest in east China over the period 2011-2015, to evaluate the impact of inorganic nutrient addition on soil bacterial communities. Four treatments were administered (control and nutrient-enrichment: $\mathrm{N}, \mathrm{P}$, and $\mathrm{N}+\mathrm{P}$ ), with $\mathrm{N}$ added at a total of $100 \mathrm{~kg} \mathrm{~N} \mathrm{ha}^{-1} \mathrm{yr}^{-1}$ in the form of $\mathrm{NH}_{4} \mathrm{NO}_{3}$, and $\mathrm{P}$ at $50 \mathrm{~kg} \mathrm{P} \mathrm{ha}^{-1} \mathrm{yr}^{-1}$ in $\mathrm{Ca}\left(\mathrm{H}_{2} \mathrm{PO}_{4) 2}\right.$, sprayed near the soil surface at the end of each trimester. Quantitative PCR technique and Illumina platform-based sequencing analysis of the V3-V4 16S rRNA gene region were performed on total DNA extracted from soil samples to characterize the soil bacterial community abundance and diversity. As Proteobacteria, Acidobacteria and Actinobacteria were the predominant phyla in all conditions, treatments did not alter the distribution of bacterial phyla, while their relative abundances responded differently to $\mathrm{N}, \mathrm{P}$ additions. A GLMM analysis showed that $N$ input significantly $(P<0.05)$ reduced the relative abundance of Acidobacteria $(13.11 \%)$, Bacteroidetes $(0.6 \%)$, Elusimicrobia (0.21\%), Nitrospirae $(0.1 \%)$ and TM6 $(0.04 \%)$. Relative abundance after P treatment significantly $(P<0.01)$ decreased for Nitrospirae $(0.07 \%)$, and pronounced interactive effects of $\mathrm{N}$ and $\mathrm{P}$ additions $(\mathrm{N}: \mathrm{P})$ were observed on phylum Nitrospirae $(P<0.01)$ and TM6 $(P<0.05)$. Moreover, redundancy analysis revealed that soil $\mathrm{pH}$ was closely related to the bacterial community $\left(r^{2}=\right.$ $0.622, P=0.015)$. Our findings suggest that exogenous $N$ and $P$ inputs affected the relative abundances and caused compositional shifts in the local bacterial community that closely associated with soil $\mathrm{pH}$, thus providing the evidence that microbe-soil interactions are influenced by $\mathrm{N}$ and $\mathrm{P}$ availability in subtropical forest ecosystem of east China.
\end{abstract}

Keywords: 16S rRNA, Nitrogen and Phosphorus Additions, Bacterial Populations, Soil PH, Subtropical Secondary Castanopsis sclerophylla Forest

\section{Introduction}

Atmospheric $\mathrm{N}$ deposition has increased dramatically since the industrial revolution due to fertilization and fossil fuel burning (Galloway et al. 2008, Peñuelas et al. 2015), and the increases in $\mathrm{N}$ inputs greatly affect soil chemical properties (Lucas et al. 2011, Tian \& Niu 2015). A recent study suggests that $\mathrm{N}$ deposition has contributed to a $4.78 \%$ increase in the total carbon (C) storage of China's forests between 1981 and 2010 (Gu et al. 2015). On the other side, N
(1) School of Forestry and Landscape Architecture, Anhui Agricultural University, Hefei 230036 (China); (2) College of Life and Environment Sciences, Huangshan University, Huangshan 245041 (China)

\section{@ Xiaoniu Xu (xnxu2007@ahau.edu.cn)}

Received: Nov 02, 2017 - Accepted: Oct 16, 2018

Citation: Teng Z, Cui J, Wang J, Fu X, Xu X (2018). Effect of exogenous nitrogen and phosphorus inputs on the microbe-soil interaction in the secondary Castanopsis sclerophylla forest in east China. iForest 11: 794-801. - doi: 10.3832/ifor2673-011 [online 2018-12-14]

Communicated by: Giorgio Alberti deposition causes soil acidification (Lu et al. 2014, Tian \& Niu 2015, Mao et al. 2017), which has become a significant threat to soil functions. He et al. (2015) reported that the intensity of $\mathrm{N}$ deposition in China is equal or even exceeds those in Europe and America, raising general concerns from the government and the public. Some previous studies indicated that $\mathrm{N}$ deposition often stimulates forest growth and enhances carbon sequestration (De Vries et al. 2006, Thomas et al. 2010), but the expected growth acceleration may be diminished when the accompanied $\mathrm{P}$ supply is deficient (Li et al. 2016a). In the context of low soil $\mathrm{P}$ contents in terrestrial ecosystems across most areas of China (Han et al. 2005), the role of $P$ deposition is relevant, as the high-level $\mathrm{N}$ deposition, which initially stimulated forest growth, is likely shifting large areas of China's forests towards $\mathrm{P}$ limitation. Moreover, soil $\mathrm{P}$ avail- 
ability in terrestrial ecosystems is primarily driven by mineral weathering, application of fertilizer inputs and atmospheric deposition (Vitousek et al. 2010, Maranguit et al. 2017). Recent assessments of observed and modeled $\mathrm{P}$ deposition rates on a global scale (Mahowald et al. 2008, Wang et al. 2015) showed a range of 0.01-1.0 kg P ha$\mathrm{yr}^{-1}$ on land.

In forest ecosystems, dominant tree species influence the metabolic abilities of soil microbial communities directly through litter production and root exudation, and indirectly by affecting soil properties. Soil microbial communities interact with site-dependent factors controlling organic matter decomposition and carbon sequestration, providing a key to understand terrestrial ecosystem feedback to global climate (Singh et al. 2010). In general, $\mathrm{N}$ addition tends to decrease microbial diversity, increase the relative abundance of copiotrophic (i.e., fast-growing, low carbon-use efficiency) taxa (e.g., Proteobacteria and Bacteroidetes), and reduce that of oligotrophic (i.e., slow-growing, high carbonuse efficiency) taxa (e.g., Acidobacteria and Basidiomycota - Fierer et al. 2007, Leff et al. 2015, Ho et al. 2017). On the other hand, soil bacteria constitute the main type of soil microorganisms, and play an extremely important role in soil structure and nutrient cycling (Nemergut et al. 2013), the formation and decomposition of organic matter (Barker 1949), the regulation of plant growth (Glick et al. 1999), and the improvement of the ecological environment. Previous research has shown that bacterial community structure can reflect the soil current situation and tendency, indicating the soil ecological function and measuring the effects of environmental governance methods (Stefanowicz et al. 2010). However, knowledge of soil bacterial response to exogenous $\mathrm{N}$ and $\mathrm{P}$ inputs is still limited, and the mechanisms that control the microbe-soil nutrient cycling remain elusive.

The recent development of high-throughput sequencing techniques (Loman et al. 2012) has overcome the intrinsic limitation of traditional microbial culturing techniques (Nichols et al. 2010), thus improving the structural analysis of soil microbial communities (Roesch et al. 2007) as well as identifying previously unknown microbial taxa (Bucbe et al. 2009, Lu et al. 2009). With the development of techniques for structural analysis of soil microbial communities, high-throughput sequencing has revolutionized the field of soil microbial ecology. In particular, the 16S rRNA gene sequence, which contains highly conserved primer-binding sites and hypervariable, species-specific regions (Kolbert \& Persing 1999), is often used for the identification and classification of bacteria (Smets et al. 2016), providing a deep insight into the diversity of soil microbial communities. Additionally, the sequencing of bacterial $16 \mathrm{~S}$ rRNA marker shows the potential for forest soil analysis. The spatial and temporal factors, which will undoubtedly come into play for soil comparisons, had little influence on soil traceability using this method (Jesmok et al. 2016). Although 16S rRNA sequencing was extensively used to characterize microbial communities of forest soils worldwide (Priha et al. 2001, Grayston \& Prescott 2005), including China (Chan et al. 2010), it was rarely considered in relation to specific forest soil treatments, such as $\mathrm{N}$ and $\mathrm{P}$ fertilization (Zheng et al. 2017).

In this study, we used high-throughput 16S rRNA sequencing method to explore the soil bacterial community diversity after $\mathrm{N}$ and $\mathrm{P}$ additions in a subtropical secondary Castanopsis sclerophylla forest. The objective was to test the effects of exogenous $\mathrm{N}$ and $\mathrm{P}$ inputs on forest soil properties and bacterial populations, and to determine the soil properties associated to the treatment-dependent compositional shifts of the local bacterial community. This investigation can strengthen our understanding of the effect of aggravated atmospheric deposition on soil microbial composition, and supplement the theoretical basis for the further study of the microbe-soil nutrient cycling mechanisms in subtropical forest ecosystem.

\section{Materials and methods}

\section{Study sites}

A field-simulated experiment was carried out from June 2011 to June 2015 in Jitan, Shitai County in the south part of Anhui Province, eastern China ( $30^{\circ} 01^{\prime} 47^{\prime \prime} \mathrm{N}, 117^{\circ}$ $21^{\prime} 23^{\prime \prime} \mathrm{E}-\mathrm{Li}$ et al. 2016b). The overall climate in this region is a typical subtropical monsoon climate, with warm and humid summers, cold and dry winters. The study area is located at elevation from 100 to 150 $\mathrm{m}$ a.s.l. The mean annual temperature is 16 ${ }^{\circ} \mathrm{C}$, with the highest of $38.8^{\circ} \mathrm{C}$ and lowest of $-8.9^{\circ} \mathrm{C}$. Mean annual precipitation is 1521 $\mathrm{mm}$ with uneven distribution, mainly from April to September ( Li et al. 2016b). The soil in this area has been classified as yellow brown earth (Chinese Soil Taxonomic Classification) with acidic pH. Castanopsis sclerophylla was the main species with the dominance of $80-90 \%$ at the study site. The stem density was 800-1189 trees $\mathrm{hm}^{-2}$ (DBH $\geq 5 \mathrm{~cm}$ ), and the largest DBH was $30.6 \mathrm{~cm}$. Other associated species were Liquidambar formosana and Pinus massoniana in the overstory and Loropetalum chinensis, Camellia cuspidata, Elaeagnus pungens and Lindera aggregata in the understory.

\section{Experimental design}

In 2011, a 43-years-old secondary Castanopsis sclerophylla forest was selected as experimental field. A moderate thinning has been conducted in this forest in 2008, and thereafter no management disturbances occurred. A randomized block design was used to avoid spatial heterogeneity. We chose three blocks with similar stand growths, species composition and site conditions to establish four treatments in each block: Control (CK), $\mathrm{N}$ addition (100 kg N $\mathrm{ha}^{-1} \mathrm{yr}^{-1}$ ), $\mathrm{P}$ addition (50 kg N ha $\mathrm{yr}^{-1}$ ), and $\mathrm{N}+\mathrm{P}$ addition (100 kg N ha-1 $\mathrm{yr}^{-1}+50 \mathrm{~kg} \mathrm{P} \mathrm{ha}^{-1}$ $\left.\mathrm{yr}^{-1}\right)$. In total, twelve $15 \times 15 \mathrm{~m}$ plots were established with 8-10 m buffer strip between plots to avoid the interaction between treatments. $\mathrm{N}$ was added as $\mathrm{NH}_{4} \mathrm{NO}_{3}$ and $\mathrm{P}$ as $\mathrm{Ca}\left(\mathrm{H}_{2} \mathrm{PO}_{4}\right)_{2}$, which were sprayed near the soil surface at the end of each trimester from June 2011. All N and P treatments were mixed evenly with $20 \mathrm{~L}$ of stream water and sprayed by a handworked backpack sprayer, while each control plot received $20 \mathrm{~L}$ stream water with no $\mathrm{N}$ or $\mathrm{P}$ applications.

\section{Soil sampling}

Soil samples were collected on July 20, 2015. In preparation for sampling, we sterilized the sieve $(2 \mathrm{~mm})$ and the head of the handhold steel auger $(6 \mathrm{~cm}$ internal diameter) in the high-pressure steam sterilization pot, and used the atmospheric-pressure steam sterilization pot for sterilizing the low-pressure polyethylene bags in laboratory the day before. Within each plot, five surface soil subsamples $(0-10 \mathrm{~cm})$ were randomly collected after removal of the litter layer, using the handhold steel auger. Totally 60 samples were collected into sterilized sealed polyethylene bags, and transported to the laboratory in a cooler box with ice bags. The samples were then passed through the sterilized sieve to remove roots and other debris, and divided into two equal parts. One was stored at 4 ${ }^{\circ} \mathrm{C}$ (fridge) until further analyses on soil physicochemical properties, and the other was combined into one composite sample for each plot, and then stored at $-20^{\circ} \mathrm{C}$ prior to genomic DNA extraction.

\section{Soil physicochemical analysis}

Soil water content (SWC) was measured by oven-drying at $105{ }^{\circ} \mathrm{C}$ to a constant weight. Soil $\mathrm{pH}$ and EC were determined using a $\mathrm{pH} / \mathrm{EC}$ meter in 1:2.5 and 1:5 soil/water suspensions, respectively. Ammonium nitrogen $\left(\mathrm{NH}_{4}{ }^{+} \mathrm{N}\right)$ and nitrate nitrogen $\left(\mathrm{NO}_{3}^{-}-\mathrm{N}\right)$ were measured by a flow injection auto-analyzer $\left(\mathrm{FIAStar}^{\circledast} 5000, \mathrm{FOSS}\right.$, Denmark), as well as the total phosphorus (TP) after micro-Kjeldahl digestion. Soil organic carbon (SOC) and total nitrogen (TN) were measured with a CN Analyzer (EA 3000 ${ }^{\circledR}$, Vector, Italy). The $\mathrm{C} / \mathrm{N}$ ratio was calculated as SOC divided by TN. Microbial biomass carbon (MBC) and nitrogen (MBN) were quantified using the chloroform fumigation-extraction method. Subsamples of fresh soil (30 g) were extracted with 100 $\mathrm{mL}$ of $0.5 \mathrm{M} \mathrm{K}_{2} \mathrm{SO}_{4}$ solution. Samples were shaken for $30 \mathrm{~min}$ and then filtered, while separate subsamples were fumigated with ethanol-free chloroform for $24 \mathrm{~h}$ at $25^{\circ} \mathrm{C}$ and then extracted. Soil dissolved organic carbon (DOC - Jones \& Willett 2006) in extracts was immediately determined using a TOC auto-analyzer (Multi N/C 3100 ${ }^{\oplus}$, Jena Analytik, Germany). The difference in total $\mathrm{N}$ between extracts of fumigated and non- 
fumigated soils (NFE) was used for estimating MBN using the expression (Jenkinson 1988): $M B N=N F E / 0.54\left(\mathrm{mg} \mathrm{kg}^{-1}\right)$. The difference in DOC content between fumigated and non-fumigated (CFE) extracts was used for $M B C$ estimation using the expression (Wu et al. 1990): $\mathrm{MBC}=$ CFE / 0.45 $\left(\mathrm{mg} \mathrm{kg}^{-1}\right)$.

\section{DNA extraction and $16 \mathrm{~S}$ rRNA gene sequencing}

We used the FastDNA ${ }^{\text {TM }}$ SPIN Kit for soil (50 preps, MPbio, USA) to extract total DNA of soil microorganisms according to the manufacturer instructions. Afterward, using the 12 composite DNA samples as a template and the primer (319F 5'-ACTCCTACGGGAGGCAGCAG-3'; 806R 5'-GGACTACHVGGGTWTCTAAT-3'), we amplified the $V_{3}$ $V_{4}$ region of the bacterial $16 \mathrm{~S}$ rRNA. All reactions were carried out in $25 \mu \mathrm{L}$ (total volume) mixtures containing approximately $25 \mathrm{ng}$ of genomic DNA extract, 12.5 $\mu \mathrm{L}$ PCR Premix, $2.5 \mu \mathrm{L}$ of each primer, and PCRgrade water to adjust the volume. PCR reactions were performed in a Master cycler gradient thermocycler (Eppendorf, Hamburg, Germany) set to the following conditions: initial denaturation at $98^{\circ} \mathrm{C}$ for $30 \mathrm{~s}$; 35 cycles of denaturation at $98{ }^{\circ} \mathrm{C}$ for $10 \mathrm{~s}$, annealing at $54 / 52{ }^{\circ} \mathrm{C}$ for $30 \mathrm{~s}$, and extension at $72{ }^{\circ} \mathrm{C}$ for $45 \mathrm{~s}$; and then final extension at $72{ }^{\circ} \mathrm{C}$ for $10 \mathrm{~min}$. The PCR products were confirmed with $2 \%$ agarose gel electrophoresis. Throughout the DNA extraction process, ultrapure water, instead of a sample solution, was used to exclude the possibility of false-positive PCR results as a negative control. The PCR products were normalized by AxyPrep ${ }^{T M}$ Mag PCR Normalizer (Axygen Biosciences, Union City, CA, USA), which allowed for the skipping of the quantifications step regardless of the $P C R$ volume submitted for sequencing. The amplicon pools were prepared for sequencing with AMPure $\mathrm{XT}^{\oplus}$ beads (Beckman Coulter Genomics, Danvers, MA, USA) and with the Library Quantification Kit for Illumina (Kapa Biosciences, Woburn, MA, USA), respectively. PhiX Control library (IIlumina) was combined with the amplicon library (expected at 30\%). The total library was sequenced either on 300PE MiSeq runs using the standard Illumina sequencing primers (Cui et al. 2017).

\section{Statistical analyses}

According to the relative abundances, we divided the soil bacterial phyla into three parts: common phyla (>10\%), rare common phyla $(1-10 \%)$, and rare phyla $(<1 \%)$. The operational taxonomic unit (OTU) was defined as a group of sequences with the same restriction profiles. Chao1 (SChao1) was determined according to methods described by Chao (1984). The relative average abundance of phyla prevalent in soils from different treatments was calculated using the package Excel $2007^{\circledast}$ (Microsoft, Redwoods, CA, USA). Indices of bacteria biodiversity were estimated based on the
OTUs using the methods of QIME (Caporaso et al. 2010), and Shannon-Wiener index (eqn. 1) and Simpson index (eqn. 2) were calculated as follows:

$$
\begin{aligned}
& H^{\prime}=-\sum_{i=1}^{S} p_{i} \log _{2} p_{i} \\
& D=1-\sum_{i=1}^{S} p_{i}^{2}
\end{aligned}
$$

For bacterial diversity, $\mathrm{n}$ is the number of OTUs, and $p_{\mathrm{i}}$ is the percentage of clones of the ith OTU, where $S$ and $N$ denote the total number of OTUs and number of clones in a library respectively, and $p_{i}=n_{i} / N$.

We used generalized linear mixed models (GLMMs) to evaluate the effect of N, P additions on the soil property and bacterial response variables. The bacterial response was set as the dependent variable, the main effect of block was built as the random effect, and the fixed effects consisted of both $\mathrm{N}$ and $\mathrm{P}$ treatments. The subplot replicates were regarded as a further random effect nested within the random effect of block to fit one of the soil properties as the dependent variable. Results were considered significant at $P$-value $\leq$ 0.05. The GLMMs analysis was conducted using the "Imer" function of the Ime4 package (Bates \& Maechler 2009) and the R statistical software (ver. 3.4.4 - http:// www.r-project.org/). Liner model was selected according to the Detrended Correspondence Analysis (DCA), and we used forward selection of variance inflation factors (VIF) to gradually filter the explanatory variables (rejecting the variables with VIF > 20). Consequently, 11 soil parameters were calculated in the redundancy analysis

Tab. 1 - Outcome of the GLMMs model on the effect of $\mathrm{N}$ and $\mathrm{P}$ treatments and their

\begin{tabular}{|c|c|c|c|c|c|c|}
\hline \multirow{2}{*}{$\begin{array}{l}\text { Soil } \\
\text { property }\end{array}$} & \multicolumn{2}{|c|}{$\mathbf{N}$} & \multicolumn{2}{|c|}{$\mathbf{P}$} & \multicolumn{2}{|c|}{$N: P$} \\
\hline & $\mathrm{F}$ & $P$ & $\mathrm{~F}$ & $P$ & $\mathbf{F}$ & $P$ \\
\hline SWC & 2.222 & 0.142 & 64.285 & $<0.001$ & 0.949 & 0.334 \\
\hline $\mathrm{pH}$ & 80.227 & $<0.001$ & 29.407 & $<0.001$ & 11.175 & 0.002 \\
\hline $\mathrm{EC}$ & 37.542 & $<0.001$ & 116.358 & $<0.001$ & 7.892 & 0.007 \\
\hline $\mathrm{NH}_{4}{ }^{+}-\mathrm{N}$ & 48.218 & $<0.001$ & 48.988 & $<0.001$ & 14.792 & $<0.001$ \\
\hline $\mathrm{NO}_{3}-\mathrm{N}$ & 64.986 & $<0.001$ & 0.251 & 0.618 & 41.510 & $<0.001$ \\
\hline DOC & 2.761 & 0.102 & 3.610 & 0.063 & 3.072 & 0.085 \\
\hline DON & 14.074 & $<0.001$ & 3.485 & 0.067 & 17.681 & $<0.001$ \\
\hline$M B C$ & 0.150 & 0.700 & 197.642 & $<0.001$ & 2.995 & 0.089 \\
\hline MBN & 0.001 & 0.981 & 109.537 & $<0.001$ & 5.780 & 0.020 \\
\hline$M B C / M B N$ & 0.288 & 0.594 & 12.985 & 0.001 & 3.859 & 0.055 \\
\hline SOC & 0.922 & 0.341 & 4.158 & 0.046 & 0.762 & 0.386 \\
\hline TP & 0.793 & 0.378 & 95.887 & $<0.001$ & 14.264 & $<0.001$ \\
\hline AP & 4.328 & 0.042 & 8.601 & 0.005 & 1.188 & 0.281 \\
\hline $\mathrm{TN}$ & 0.963 & 0.331 & 1.912 & 0.172 & 0.725 & 0.398 \\
\hline SOC/TN & 0.000 & 0.987 & 74.492 & $<0.001$ & 21.270 & $<0.001$ \\
\hline $\mathrm{SOC} / \mathrm{TP}$ & 0.015 & 0.903 & 33.686 & $<0.001$ & 0.101 & 0.752 \\
\hline TN/TP & 0.001 & 0.982 & 11.728 & 0.001 & 2.327 & 0.135 \\
\hline $\mathrm{K}$ & 1.881 & 0.178 & 0.011 & 0.916 & 2.299 & 0.137 \\
\hline $\mathrm{Ca}$ & 29.217 & $<0.001$ & 89.478 & $<0.001$ & 8.217 & 0.006 \\
\hline $\mathrm{Mg}$ & 29.696 & $<0.001$ & 0.333 & 0.566 & 2.104 & 0.153 \\
\hline
\end{tabular}
interaction effect ( $\mathrm{N}: \mathrm{P})$ on soil physicochemical properties.
(RDA) for determining the relationship between environmental factors and the distribution of soil bacterial communities, represented by relative abundance of each OTUs. Monte Carlo permutation test was further applied to compute statistical significance $(n=999)$. The results of RDA analysis were visualized in the form of a biplot ordination diagram constructed by the R software.

\section{Results}

\section{Soil physicochemical properties}

As expected, soil physicochemical properties responded differently to $\mathrm{N}$ and $\mathrm{P}$ applications. $\mathrm{N}$ input had significant effect on the soil $\mathrm{pH}, \mathrm{EC}, \mathrm{NH}_{4}^{+}-\mathrm{N}, \mathrm{NO}_{3}^{-} \mathrm{-N}, \mathrm{DON}, \mathrm{Ca}$, $M g(P<0.001)$ and AP $(P<0.05)$, whereas $P$ input affected several parameters significantly, such as SWC, pH, EC, $\mathrm{NH}_{4}{ }^{+} \mathrm{N}, \mathrm{MBC}$, MBN, MBC/MBN, SOC, TP, AP, SOC/TN, SOC/TP, TN/TP and Ca $(P<0.05)$. Furthermore, the interaction effect of $\mathrm{N}: \mathrm{P}$ had pronounced influence on the contents of soil $\mathrm{pH}, \mathrm{EC}, \mathrm{NH}_{4}{ }^{+}-\mathrm{N}, \mathrm{NO}_{3}{ }^{-} \mathrm{N}, \mathrm{DON}, \mathrm{MBN}, \mathrm{TP}$ and SOC/TN (Tab. 1). On the other hand, after $\mathrm{N}, \mathrm{P}$ treatments, soils $\mathrm{pH}$ in the study area were more acidic, with $\mathrm{pH}$ dropping from 4.8 to 4.3 (see Tab. S1 in Supplementary material). The contents of $\mathrm{pH}, \mathrm{Mg}$, SOC/TP and TN/TP decreased significantly after $\mathrm{N}+\mathrm{P}$ addition, whereas the contents of $\mathrm{EC}$, $\mathrm{NH}_{4}^{+}{ }^{-} \mathrm{N}, \mathrm{NO}_{3}^{-}-\mathrm{N}, \mathrm{DOC}, \mathrm{MBC}, \mathrm{MBN}, \mathrm{TP}, \mathrm{K}$ and AP increased obviously compared with $\mathrm{CK}$ $(P<0.05-$ Tab. S1 $)$.

\section{Soil bacterial diversity}

Based on the results of the GLMMs model, $\mathrm{N}$ and $\mathrm{P}$ treatments did not produce significant shifts in species richness, as well as 
Tab. 2 - Comparison of clone libraries of bacteria at phylum and class levels from forest soils at four different treatments. Number of OTUs $>5$.

\begin{tabular}{|c|c|c|c|c|c|c|c|c|c|}
\hline \multirow{2}{*}{ Phylum } & \multirow{2}{*}{ Class } & \multicolumn{2}{|c|}{ Control (CK) } & \multicolumn{2}{|l|}{$\mathrm{N}$} & \multicolumn{2}{|l|}{$\mathrm{N}+\mathrm{P}$} & \multicolumn{2}{|l|}{$\mathbf{P}$} \\
\hline & & OTUs & $\%$ & OTUs & $\%$ & OTUs & $\%$ & OTUs & $\%$ \\
\hline \multirow[t]{5}{*}{ Proteobacteria } & (all) & 12606.50 & 46.28 & 7509.00 & 46.31 & 6237.67 & 40.07 & 8709.00 & 40.34 \\
\hline & $\alpha$-proteobacteria & 10349.00 & 38.15 & 6702.00 & 41.30 & 5218.00 & 33.55 & 7384.00 & 34.16 \\
\hline & $\gamma$-proteobacteria & 892.50 & 3.13 & 481.00 & 2.98 & 635.00 & 4.05 & 659.00 & 3.08 \\
\hline & $\delta$-proteobacteria & 652.00 & 2.39 & 214.67 & 1.33 & 295.33 & 1.90 & 473.00 & 2.18 \\
\hline & $\beta$-proteobacteria & 710.00 & 2.60 & 111.00 & 0.69 & 88.00 & 0.56 & 192.67 & 0.91 \\
\hline Acidobacteria & - & 8459.50 & 32.97 & 3127.67 & 19.86 & 3145.33 & 19.09 & 6461.00 & 32.55 \\
\hline Actinobacteria & - & 2818.50 & 11.25 & 2906.33 & 18.05 & 4229.67 & 26.99 & 3043.67 & 15.35 \\
\hline Chloroflexi & - & 550.00 & 2.08 & 529.67 & 3.33 & 482.67 & 3.01 & 498.67 & 2.59 \\
\hline AD3 & - & 328.50 & 1.37 & 479.00 & 2.99 & 492.00 & 3.18 & 400.33 & 2.15 \\
\hline Planctomycetes & - & 263.50 & 1.27 & 379.00 & 2.41 & 211.33 & 1.25 & 180.33 & 1.10 \\
\hline Bacteroidetes & - & 234.50 & 0.88 & 46.00 & 0.28 & 86.33 & 0.54 & 149.33 & 0.68 \\
\hline WPS-2 & - & 234.00 & 0.85 & 436.33 & 2.76 & 353.67 & 2.16 & 258.67 & 1.32 \\
\hline Verrucomicrobia & - & 223.00 & 0.87 & 345.67 & 2.21 & 229.67 & 1.42 & 317.33 & 1.67 \\
\hline Firmicutes & - & 192.00 & 0.76 & 143.67 & 0.89 & 135.67 & 0.86 & 120.67 & 0.59 \\
\hline Gemmatimonadetes & - & 153.50 & 0.54 & 36.67 & 0.22 & 42.67 & 0.28 & 131.33 & 0.57 \\
\hline Elusimicrobia & - & 80.00 & 0.27 & 9.00 & 0.06 & 6.67 & 0.04 & 39.00 & 0.21 \\
\hline Nitrospirae & - & 25.00 & 0.10 & 0.33 & 0.00 & 0.00 & 0.00 & 5.00 & 0.03 \\
\hline Cyanobacteria & - & 22.50 & 0.08 & 15.67 & 0.10 & 8.67 & 0.05 & 41.00 & 0.27 \\
\hline Chloroplast & - & 21.50 & 0.12 & 4.00 & 0.03 & 8.67 & 0.05 & 15.33 & 0.08 \\
\hline TM6 & - & 17.00 & 0.07 & 4.33 & 0.03 & 13.67 & 0.09 & 11.67 & 0.06 \\
\hline $\begin{array}{l}\text { candidatus } \\
\text { Saccharibacteria }\end{array}$ & - & 15.00 & 0.06 & 41.33 & 0.26 & 95.00 & 0.60 & 41.33 & 0.18 \\
\hline FCPU426 & - & 13.50 & 0.06 & 7.00 & 0.04 & 6.67 & 0.04 & 13.00 & 0.06 \\
\hline
\end{tabular}

in the tested diversity indices, like the number of observed species (OTUs), ShannonWiener index, Simpson index and Chao1 index (Tab. S2 in Supplementary material).

\section{Bacterial community composition}

Proteobacteria-, Acidobacteria-, and Actinobacteria-associated OTUs accounted for more than $84 \%$ of the total, and these common phyla were the most abundant in both treatments and control (Tab. 2). The rare common phyla accounted for nearly 9\% and the rare only took up less than $7 \%$ (Tab. 2). Proteobacteria was the most

abundant bacterial phylum, and contained four primary classes out of six from the database of detected OTUs ( $\alpha-, \beta-, \gamma$ - and $\delta$ proteobacteria, number of OTUs $>5-$ Fig. 1). Among the clone library of subgroup $a-$ proteobacteria, the relative abundance decreased by $4.6 \%$ and $3.99 \%$ after $\mathrm{N}+\mathrm{P}$ and $\mathrm{P}$ additions respectively, whereas increased by $3.15 \%$ after $\mathrm{N}$ additions. For $\gamma$-proteobacteria, the relative abundance decreased by $0.15 \%$ and $0.05 \%$ after $\mathrm{N}$ and $\mathrm{P}$ additions, whereas increased by $0.92 \%$ after $\mathrm{N}+\mathrm{P}$ additions. Moreover, notable changes were observed among four treatments of ambient

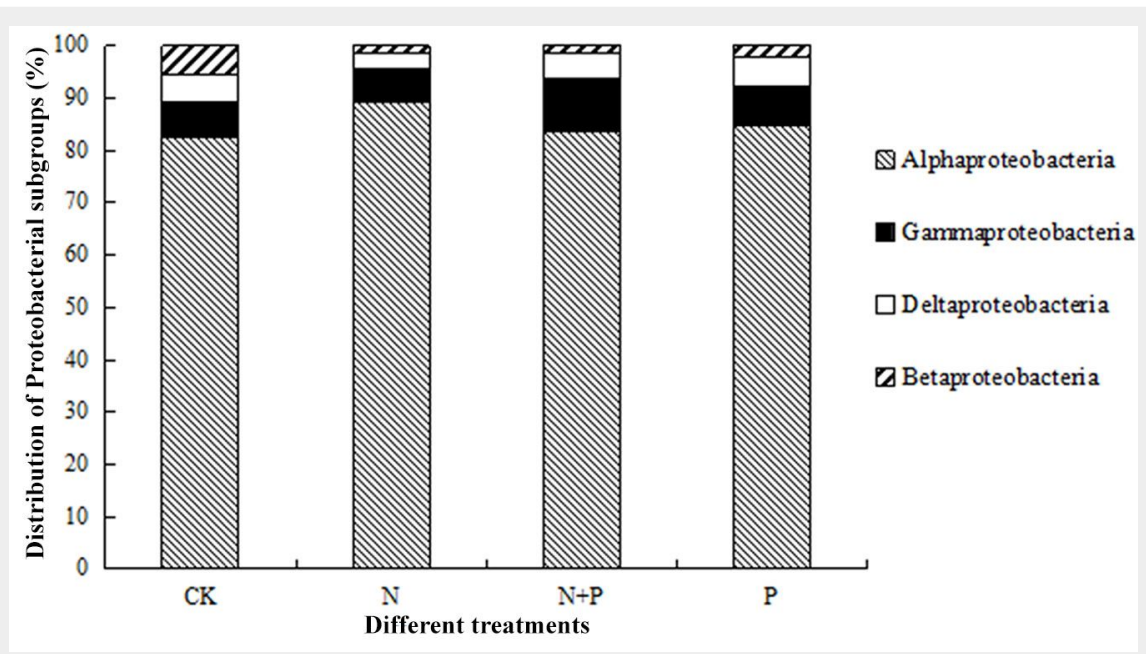

Fig. 1 - Proportions of four dominant Proteobacteria subgroups in the soil samples from different treatment plots. and addition for some other phyla (Fig. 2). As reported in Tab. 2 and Tab. S3 (Supplementary material), we found that $\mathrm{N}$ addition significantly $(P<0.05)$ reduced the relative abundances of specific taxonomic groups compared to the control, specifically for Acidobacteria (13.11\%), Bacteroidetes (0.6\%), Elusimicrobia (0.21\%), Nitrospirae $(0.1 \%)$ and TM6 (0.04\%). The $P$ addition significantly $(P<0.01)$ reduced the relative abundances of Nitrospirae (0.07\%). Additionally, the GLMM analysis showed pronounced interactive effects of $\mathrm{N}$ and $\mathrm{P}$ additions $(\mathrm{N}: \mathrm{P})$ on phylum Nitrospirae $(P<$ $0.01)$ and TM6 $(P<0.05-$ Tab. S3 in Supplementary material).

Various results were found among the bacteria when the genus level was considered. Compared with CK treatment (control), $\mathrm{N}$ addition significantly $(P<0.05)$ decreased by $81.56 \%$ the number of OTUs in the genus Burkholderia (Proteobacteria), by $72.39 \%$ in Gp2 (Acidobacteria), $100 \%$ in Ohtaekwangia (Bacteroidetes), $42.86 \%$ in Cohnella (Firmicutes) and 100\% in Nitrospira in phylum Nitrospirae (Tab. S4 in Supplementary material). The $\mathrm{N}+\mathrm{P}$ treatment significantly increased by $121.47 \%$ the number of OTUs in the genus Conexibacter (Actinobacteria), $533.33 \%$ in Saccharibacteria genera incertae sedis (candidatus Saccharibacteria), and mostly reduced the OTUs by 86.57\% $(P<0.05)$ in the genus Burkholderia (Proteobacteria), $78.04 \%$ in Gp2 (Acidobacteria), $93.55 \%$ in Ohtaekwangia (Bacteroidetes) and $47.62 \%$ in Cohnella (Firmicutes). Moreover, $\mathrm{P}$ addition largely decreased $(P$ $<0.05)$ the OTUs of Burkholderia in Pro- 
Fig. 2 - Shifts of soil bacterial relative abundance at phylum level after $\mathrm{N}$ and $\mathrm{P}$ additions from different treatment plots. Error bars represent the standard error.
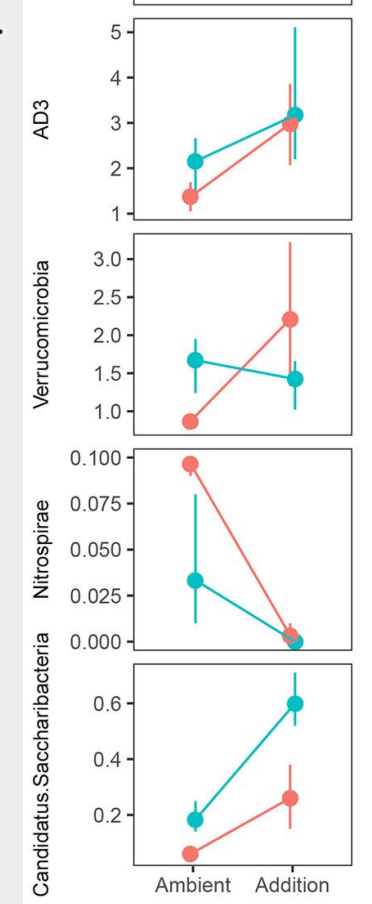
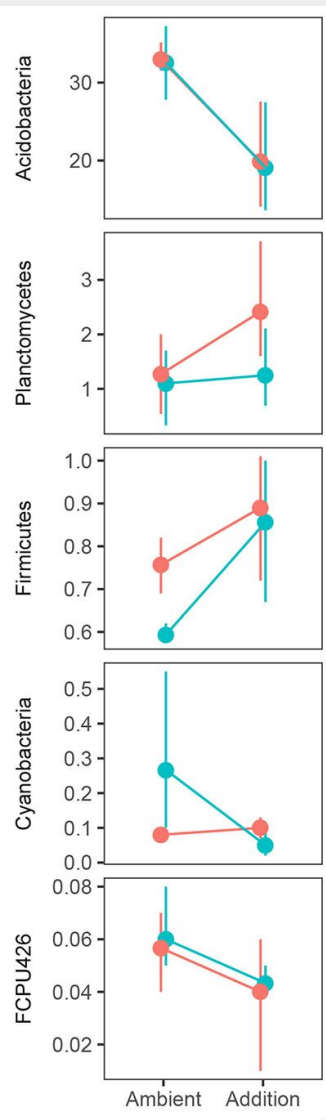
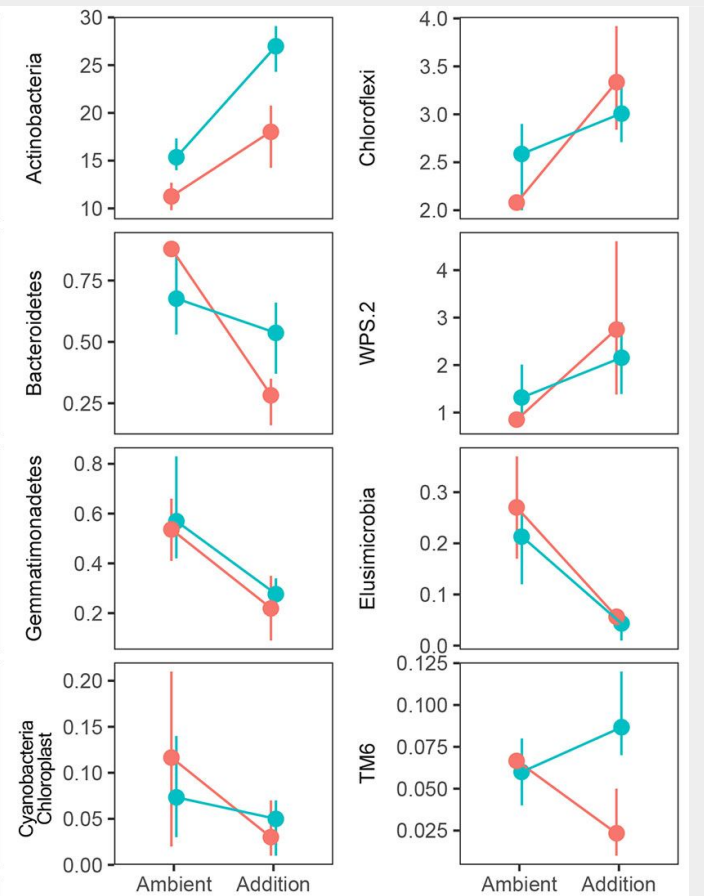

$\mathrm{P}$

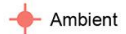

Addition

$\mathrm{N}$ treatment

teobacteria (-69.34\%), Gp3 in Acidobacteria $(-52.39 \%)$, Cohnella in Firmicutes (-80.95\%) and Nitrospira in Nitrospirae $(-76.47 \%)$. Additionally, the genus Gp17 was not detected after all allochthonous additions, as well as some other genera not shown after specific treatment, such as the genera $\mathrm{Hy}$ phomicrobium, Variovorax, Gp10, Ohtaekwangia, Flavitalea and Nitrosospira.

Relationship between soil physicochemical properties and bacterial populations

The RDA ordination plot shows the relationship between the phylum of bacterial populations and environmental variables (Fig. 3), which indicated that the plots subjected to the four treatments were clearly separated from each other. Altogether, the soil physicochemical properties explained $96.92 \%$ of the total variation by first two axes, and $\mathrm{pH}$ best explained the differences between treatments, which was validated by Monte Carlo permutation tests ( $P$ $=0.015-$ Tab. S5 in Supplementary material).

\section{Discussion}

Effects of $N$ and $P$ additions on soil parameters

Soil $\mathrm{pH}$ in $\mathrm{N}, \mathrm{P}$ and $\mathrm{N}+\mathrm{P}$ treatments were significantly more acidic than in control plots (Tab. S1 in Supplementary material), suggesting that $\mathrm{N}, \mathrm{P}$ additions accelerated soil acidity. Similar to our result, Tian et al.

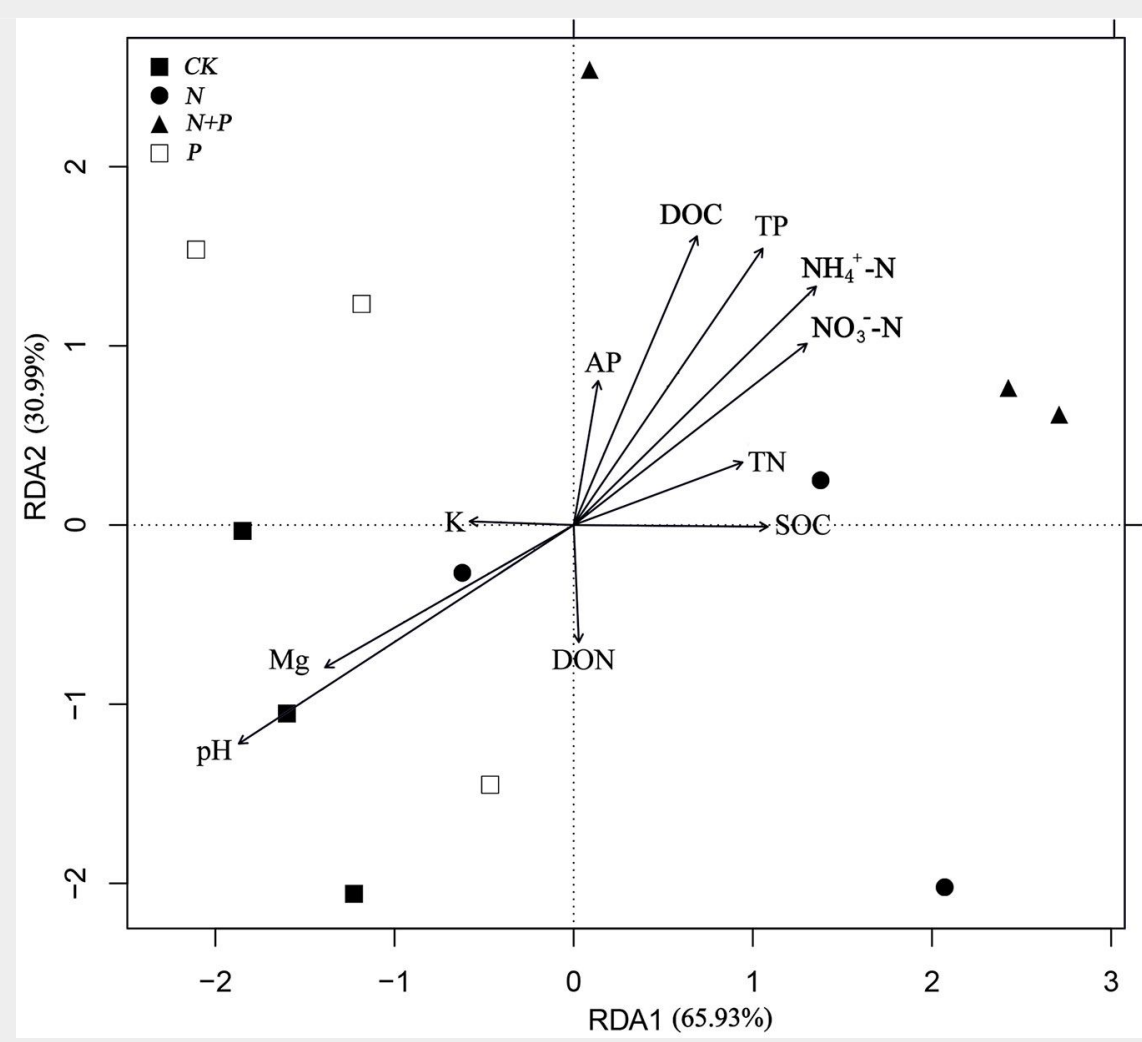

Fig. 3 - Ordination plot of the results from the redundancy analysis (RDA). The plot was used to explore the relationships between selected soil properties and bacterial community composition. Numbers in brackets represent the percentage of variation of the data explained by each factor, RDA 1 explains $65.93 \%$ of the total variation and RDA2 explains $30.99 \%$ of the total variation, respectively. The primary factors for the variables of the environmental data are represented by arrows. 
(2017) reported a decreased $\mathrm{pH}$ value after 4-year nitrogen fertilization in Guniujiang (GNJ, Anhui province), southern China, especially at 0-10 $\mathrm{cm}$ soil depth, in subtropical evergreen broad-leaf forests where the value of soil $\mathrm{pH}$ was below 5 . The recent paper by Zheng et al. (2017) about the specific effect of long-term $\mathrm{N}$ and $\mathrm{P}$ fertilization of east China forest soils, addressed the topic of the effect on inorganic $P$ solubilizing bacteria (iPSB) in alkaline soils. Its result showed that long-term $\mathrm{N}$ addition inhibited iPSB by reducing soil $\mathrm{pH}$, eventually increasing soil $\mathrm{P}$ release. Although our sampling sites belongs to acid soil, the $\mathrm{pH}$ after $\mathrm{N}$ and $\mathrm{P}$ additions decreased and the contents of TP and AP increased significantly, which suggests that IPSB populations may modulate the acidification and $P$ release in the soil. In general, after $\mathrm{N}$ saturation, excessive $\mathrm{N}$ inputs may lead to $\mathrm{N}$ supply exceeding the demand of soil microorganism and plant, causing the $\mathrm{NO}_{3}^{-}-\mathrm{N}$ loss through leaching and denitrification, which may accelerate the process of soil acidification (Tarkalson et al. 2006). Tian et al. (2016) found that $\mathrm{N}$ addition suppressed microbial biomass in subtropical forest where $\mathrm{N}$ is close to saturation, and excess $\mathrm{N}$ to these forests may lead to a high risk of $\mathrm{N}$ saturation and aggravated $\mathrm{P}$ limitation, which might further negatively affect the survival of microbial communities. On the other hand, Zhang et al. (2016) observed P alleviating the nutrient limitation and soil acidification in the Chinese fir plantations in subtropical China, which was not reflected by our findings. This may be due to the different site conditions, including tree species (evergreen broadleaved vs. coniferous forest), soil types (yellow brown vs. red soil) and other factors.

\section{Effects of $N$ and $P$ additions on bacterial populations}

As reviewed by Janssen (2006), the phylum Proteobacteria comprises the largest fraction of the bacterial community in soil ecosystems. Generally, the subgroup $a-$ Proteobacteria grows at relative lower levels of nutrients (Euzéby 1997). In our study, GLMMs analysis showed no significant difference within the class of a-Proteobacteria after $\mathrm{N}$ and $\mathrm{P}$ additions. At the genus level, however, a remarkable difference came out after nutrient additions. For example, the OTUs numbers of genus Rhizobium ( $\alpha$-Proteobacteria) decreased significantly after $\mathrm{N}$ and $\mathrm{N}+\mathrm{P}$ addition $(P<0.05)$, and Nitrospirillum and Nitrobacter (a-Proteobacteria) decreased after $\mathrm{N}+\mathrm{P}$ addition (Tab. S4). These indicate that our site may be $\mathrm{N}$ enriched and the large proportion of a-Proteobacteria may be limited by copiotrophic attributes, consistent with previous studies that $a$-Proteobacteria possibly had an oligotrophic affinity and was adapted to oligotrophy and acidic soils (Fierer et al. 2007, Naether et al. 2012). On the other hand, significant decreases were detected between treatments and control in the subgroup $\beta$-Proteobacteria. Its genus Burkholderia, which showed the largest abundance in all samples and had significant differences between treatments, is known to include efficient mineral-weathering and nitrogen-fixing bacteria (Leveau et al. 2010). In our study, however, its relative abundance decreased significantly $(P<0.05)$ after additions compared with control (Tab. $\mathrm{S}_{4}$ in Supplementary material). This may be due to the relatively high level of nutrient enrichment that increases soil nitrogen availability and weakens bacterial competitive advantage. Previous study has proved that biological nitrogen fixation is an energy-intensive process and requires a suitable reductant to support electron transport to nitrogenase (Shi et al. 2016). In the case of high levels of available $\mathrm{N}$ in the soil, the gene for nitrogen fixation will usually not express (Shi et al. 2016), which may negatively affect the growth of $\mathrm{N}$-fixing bacteria. Additionally, in assessing the effect of $\mathrm{N}$ addition on nutrient cycling processes, bacterial and archaeal nitrification and denitrification gain importance after $\mathrm{N}$ saturation, and initiated the nutrient cycling, resulting in the efflux of $\mathrm{N}$ compounds from the soil ecosystem (Aber et al. 1998). Therefore, bacteria with more efficient nitrification pathways were more likely to be selected (Freedman et al. 2013), which may lead to higher rate of nitrification despite the reduced abundance of nitrifiers and genes related to $\mathrm{N}$ cycling processes.

Acidobacteria, which is known to grow under oligotrophic and acidic environment, is physiologically diverse and ubiquitous, especially in soil. However, it has been reported that some members of Acidobacteria did not exist in the soil at relative lower pH (Barns et al. 1999). Jones et al. (2009) observed that the effect of $\mathrm{pH}$ on multiple members of Acidobacteria was not the same. This likely explain why the abundance of Acidobacteria did not increase with the decrease of soil $\mathrm{pH}$ in our study. Further analysis indicated that the response of different subgroups of Acidobacteria to soil $\mathrm{pH}$ was varied: the relative abundances of genera $G p 1,2,3,12,13$ and 15 were negatively correlated with soil $\mathrm{pH}$, while Gp4, 6, 7, 10, 11, 16, 17, 18, 22 and 25 showed positive correlations (Jones et al. 2009). Specifically, we observed that the abundance of Gp2, 3 and 6 were the predominant genera with significant differences to treatments, and showed the similar decreasing trend with soil acidification (Tab. S4). This result is partly in accordance with the findings by Zhang et al. (2014), who reported that the relative abundances of genera Gp1, 2 and 3 were significantly and positively correlated with soil $\mathrm{pH}$, while others presented opposite patterns in the Shennongjia Mountain. Some studies also revealed that other soil parameters, such as mineral element contents (Navarrete et al. 2013), soil enzyme activity (Zhang et al. 2014), and plant diversity
(Naether et al. 2012) were closely related to the abundances of certain genera, while the contribution of these factors on the change of the community composition needs to be further investigated.

\section{Conclusions}

Overall, exogenous $\mathrm{N}$ and $\mathrm{P}$ inputs did not produce significant changes to the bacterial species richness, as well as to the diversity indices, which indicate a relative balanced soil microbial community structure able to cope with external environmental shifts. On the other hand, soil bacterial populations after $\mathrm{N}$ and $\mathrm{P}$ treatments clearly differed compared with control sites, especially for several subgroups of the phyla Proteobacteria and Acidobacteria. Inorganic nutrient additions alter the status of nutrient enrichment or limitation, which may lead to variations of soil physico-chemical properties, as well as microbial quantity and activity. Moreover, soil $\mathrm{pH}$, as an overriding factor on determining bacterial community structure, closely affected the distribution of bacterial communities, which provides an insight to investigate soil microbial shifts mediated largely by microbe-soil interactions in the subtropical forest ecosystem.

\section{Acknowledgements}

This work was supported by the National Natural Science Foundation of China (NSFC, No. 31770672 and 31370626) and the National Basic Research Program of China (973 Program, No. 2010CB950602). We gratefully acknowledge Mr. ZF Wang and J Xu for the field sampling, and Dr. C Shi and Mr. T Xie for assistance with molecular biology experiments.

\section{References}

Aber J, McDowell WH, Nadelhoffer K, Magill A, Berntson G, Kamakea M, McNulty SG, Currie WS, Rustad L, Fernandez IJ (1998). Nitrogen saturation in temperate forests ecosystems. Bioscience 48 (11): 921-934. - doi: 10.2307/1313 296.-doi:10.2307/1313296

Barker H (1949). Soil bacteria: useful in studying processes of organic matter formation and decomposition. California Agriculture 3 (1): 10-10. [online] URL: http://calag.ucanr.edu/archive/?ty pe=pdf\&article=ca.voo3no1p10

Barns SM, Takala SL, Kuske CR (1999). Wide distribution and diversity of members of the bacterial kingdom Acidobacterium in the environment. Applied and Environmental Microbiology 65 (4): 1731-1737. [online] URL: http://aem.asm. org/content/65/4/1731.short

Bates D, Maechler M (2009). Ime4: linear mixedeffects models using S4 classes. R package version 0:999375-32. [online] URL: http://CRAN.Rproject.org/package/lme4

Bucbe M, Reich M, Murat C, Morin E, Nilsson RH, Uroz S, Martin F (2009). 454 pyrosequencing analyses of forest soils reveal an unexpected high fungal diversity. New Phytologist 184 (2): 449-456. - doi: 10.1111/j.1469-8137.2009.03003.x Caporaso JG, Kuczynski J, Stombaugh J, Bittinger K, Bushman FD, Costello EK, Fierer N, 
Peña AG, Goodrich JK, Gordon JI (2010). QIIME allows analysis of high-throughput community sequencing data. Nature Methods 7 (5): 335336. - doi: 10.1038/nmeth.f.303

Chan OC, Yang X, Fu Y, Feng Z, Sha L, Casper P, Zou XM (2010). 16S rRNA gene analyses of bacterial community structures in the soils of evergreen broad-leaved forests in south-west China. Fems Microbiology Ecology 58 (2): 247259. - doi: 10.1111/j.1574-6941.2006.00156.x

Chao A (1984). Non-parametric estimation of the classes in a population. Scandinavian Journal of Statistics 11 (4): 265-270. - doi: 10.2307/4615964 Cui J, Wang J, Xu J, Xu C, Xu XN (2017). Changes in soil bacterial communities in an evergreen broad-leaved forest in east China following 4 years of nitrogen addition. Journal of Soils and Sediments 17 (8): 2156-2164. - doi: 10.1007/s1136 8-017-1671-y

De Vries W, Reinds GJ, Gundersen P, Sterba H (2006). The impact of nitrogen deposition on carbon sequestration by European forests and heathlands. Global Change Biology 12 (7): 11511173. - doi: 10.1111/j.1365-2486.2006.01151.x

Euzéby JP (1997). List of bacterial names with standing in nomenclature: a folder available on the internet. International Journal of Systematic Bacteriology 47 (2): 590-592. - doi: 10.1099/ 00207713-47-2-590

Fierer N, Bradford MA, Jackson RB (2007). Toward an ecological classification of soil bacteria. Ecology 88 (6): 1354-1364. - doi: 10.1890/051839

Freedman Z, Eisenlord SD, Zak DR, Xue K, He Z, Zhou J (2013). Towards a molecular understanding of $\mathrm{N}$ cycling in northern hardwood forests under future rates of $\mathrm{N}$ deposition. Soil Biology and Biochemistry 66 (11): 130-138. - doi: 10.1016/j.soilbio.2013.07.010

Galloway JN, Townsend AR, Erisman JW, Bekunda M, Cai Z, Freney JR, Martinelli LA, Seitzinger SP, Sutton MA (2008). Transformation of the nitrogen cycle: recent trends, questions, and potential solutions. Science 320 (5878): 889-892. - doi: 10.1126/science.1136674

Glick BR, Patten CL, Holguin G, Penrose DM (1999). Nitrogen fixation: biochemical and genetic mechanisms used by plant growth promoting bacteria. Imperial College Press, London, UK, pp. 14-44.

Grayston SJ, Prescott CE (2005). Microbial communities in forest floors under four tree species in coastal British Columbia. Soil Biology and Biochemistry 37 (6): 1157-1167. - doi: 10.1016/j. soilbio.2004.11.014

Gu FX, Zhang YD, Huang M, Tao B, Yan HM, Guo $R$, Li J (2015). Nitrogen deposition and its effect on carbon storage in Chinese forests during 1981-2010. Atmospheric Environment 123 (1): 171-179. - doi: 10.1016/j.atmosenv.2015.10.081

Han W, Fang J, Guo D, Zhang Y (2005). Leaf nitrogen and phosphorus stoichiometry across 753 terrestrial plant species in China. New Phytologist 168 (2): 377-385. - doi: 10.1111/j.1469-81 37.2005.01530.x

He N, Zhu J, Wang Q (2015). Uncertainty and perspectives in studies of atmospheric nitrogen deposition in China: a response to Liu et al. (2015). Science of The Total Environment 520: 302-304. - doi: 10.1016/j.scitotenv.2015.03.063 Ho A, Di LD, Bodelier PL (2017). Revisiting life strategy concepts in environmental microbial ecology. FEMS Microbiology Ecology 93 (3): fix006. - doi: 10.1093/femsec/fixoo6

Janssen PH (2006). Identifying the dominant soil bacterial taxa in libraries of $16 \mathrm{~S}$ rRNA and $16 \mathrm{~S}$ rRNA genes. Applied and Environmental Microbiology 72 (3): 1719-1728. - doi: 10.1128/AEM.72.3. 1719-1728.2006

Jenkinson DS (1988). Determination of microbial biomass carbon and nitrogen in soil. In: "Advances in Nitrogen Cycling in Agricultural Ecosystems" (Wilson JR eds). CAB International, Wallingford, UK, pp. 368-386.

Jesmok EM, Hopkins JM, Foran DR (2016). Nextgeneration sequencing of the bacterial $16 \mathrm{~s}$ rRNA gene for forensic soil comparison: a feasibility study. Journal of Forensic Sciences 61 (3): 607-617. - doi: 10.1111/1556-4029.13049

Jones D, Willett V (2006). Experimental evaluation of methods to quantify dissolved organic nitrogen (DON) and dissolved organic carbon (DOC) in soil. Soil Biology and Biochemistry 38 (5): 991-999. - doi: 10.1016/j.soilbio.2005.08.012 Jones RT, Robeson MS, Lauber CL, Hamady M, Knight R, Fierer N (2009). A comprehensive survey of soil acidobacterial diversity using pyrosequencing and clone library analyses. ISME Journal 3 (4): 442-453. - doi: 10.1038/ismej.2008.127 Kolbert CP, Persing DH (1999). Ribosomal DNA sequencing as a tool for identification of bacterial pathogens. Current Opinion in Microbiology 2 (3): 299-305. - doi: 10.1016/S1369-5274(99)800 $52-6$

Leff JW, Jones SE, Prober SM, Barberán A, Borer ET, Firn JL (2015). Consistent responses of soil microbial communities to elevated nutrient inputs in grasslands across the globe. Proceedings of the National Academy of Sciences USA 112 (35): 10967-10972. - doi: 10.1073/pnas.150838 2112

Leveau JHJ, Uroz S, Boer WD (2010). The bacterial genus Collimonas: mycophagy, weathering and other adaptive solutions to life in oligotrophic soil environments. Environmental Microbiology 12 (2): 281-292. - doi: 10.1111/j.1462-29 20.2009.02010.x

Li Y, Niu S, Yu G (2016a). Aggravated phosphorus limitation on biomass production under increasing $\mathrm{N}$ addition: a meta-analysis. Global Change Biology 22 (2): 934-943. - doi: 10.1111/gc b. 13125

Li M, Xu J, Tian D, Yu X, Xu XN (2016b). Effect of nitrogen and phosphorus addition on litterfall production and nutrient dynamics in a Castanopsis sclerophylla secondary forest. Chinese Agricultural Science Bulletin 32 (19): 7-13. [in Chinese with English abstract]

Loman NJ, Misra RV, Dallman TJ, Constantinidou C, Gharbia SE, Wain J (2012). Performance comparison of benchtop high-throughput sequencing platforms. Nature Biotechnology 30 (5): 434-439. - doi: $10.1038 / n b t .2198$

Lu J, Domingo JWS, Hill S, Edge TA (2009). Microbial diversity and host. Applied and Environmental Microbiology 75 (18): 5919-5926. - doi: 10.1128/AEM.00462-09

Lu X, Mao Q, Gilliam FS, Luo Y, Mo J (2014). Nitrogen deposition contributes to soil acidification in tropical ecosystems. Global Change Biology 20 (12): 3790-3801. - doi: 10.1111/gcb.12665

Lucas RW, Klaminder J, Futter MN, Bishop KH,
Egnell G, Laudon H, Högberg P (2011). A metaanalysis of the effects of nitrogen additions on base cations: implications for plants, soils, and streams. Forest Ecology and Management 262 (2): 95-104. - doi: 10.1016/j.foreco.2011.03.018 Mahowald N, Jickells TD, Baker AR, Artaxo P, Benitez-Nelson CR, Bergametti G (2008). Global distribution of atmospheric phosphorus sources, concentrations, and deposition rates, and anthropogenic impacts. Global Biogeochemical Cycles 22 (4): 37-42. - doi: 10.1029/2008 GBo03240

Mao QG, Lu XK, Zhou KJ, Chen H, Zhu XM, Mori T, Mo JM (2017). Effects of long-term nitrogen and phosphorus additions on soil acidification in an N-rich tropical forest. Geoderma 285: 5763. - doi: 10.1016/j.geoderma.2016.09.017

Maranguit D, Guillaume T, Kuzyakov Y (2017). Land-use change affects phosphorus fractions in highly weathered tropical soils. Catena 149 (1): 385-393. - doi: 10.1016/j.catena.2016.10.010 Naether A, Foesel BU, Naegele V, Wüst PK, Weinert J, Bonkowski M (2012). Environmental factors affect Acidobacterial communities below the subgroup level in grassland and forest soils. Applied and Environmental Microbiology 78 (20): 7398-7406. - doi: 10.1128/AEM.01325-12 Navarrete AA, Kuramae EE, Hollander MD, Pijl AS, Veen JAV, Tsai SM (2013). Acidobacterial community responses to agricultural management of soybean in amazon forest soils. FEMS Microbiology Ecology 83 (3): 607-621. - doi: 10.1111/1574-6941.12018

Nemergut DR, Schmidt SK, Fukami T, Neill SP, Bilinski TM, Stanish LF, Knelman JE, Darcy JL, Lynch RC, Wickey P, Ferrenberg S (2013). Patterns and processes of microbial community assembly. Microbiology and Molecular Biology Reviews 77 (3): 342-356. - doi: 10.1128/MMBR. 00051-12

Nichols D, Cahoon N, Trakhtenberg EM, Pham L, Mehta A, Belanger A, Kanigan T, Lewis K, Epstein SS (2010). Use of ichip for high-throughput in situ cultivation of "uncultivable" microbial species. Applied and Environmental Microbiology 76 (8): 2445-2450. - doi: 10.1128/AEM.01 754-09

Peñuelas J, Sardans J, Rivas-Ubach A, Janssens IA (2015). The human-induced imbalance between C, N and P in Earth's life system. Global Change Biology 18 (1): 3-6. - doi: 10.1111/j.13652486.2011.02568.x

Priha O, Grayston SJ, Hiukka R, Pennanen T, Smolander A (2001). Microbial community structure and characteristics of the organic matter in soils under Pinus sylvestris, Picea abies and Betula pendula at two forest sites. Biology and Fertility of Soils 33 (1): 17-24. - doi: 10.1007/ s003740000281

Roesch LFW, Fulthorpe RR, Riva A, Casella G, Hadwin AKM, Kent AD, Daroub SH, Camargo FA, Farmerie WG, Triplett EW (2007). Pyrosequencing enumerates and contrasts soil microbial diversity. ISME Journal 1 (4): 283-290. - doi: 10.1038/ismej.2007.53

Shi HW, Wang LY, Li XX, Liu XM, Hao TY, He XJ, Chen SF (2016). Genome-wide transcriptome profiling of nitrogen fixation in Paenibacillus, sp. WLY78. BMC Microbiology 16(1): 25. - doi: 10.1186/s12866-016-0642-6

Singh BK, Bardgett RD, Smith P, Reay DS (2010). 
Microorganisms and climate change: terrestrial feedbacks and mitigation options. Nature Reviews Microbiology 8 (11): 779-790. - doi: 10.103 8/nrmicro2439

Smets W, Leff JW, Bradford MA, Mcculley RL, Lebeer S, Fierer N (2016). A method for simultaneous measurement of soil bacterial abundances and community composition via $16 \mathrm{~S}$ rRNA gene sequencing. Soil Biology and Biochemistry 96: 145-151. - doi: 10.1016/j.soilbio.20 16.02.003

Stefanowicz AM, Niklinska M, Kapusta P, SzarekLukaszewska G (2010). Pine forest and grassland differently influence the response of soil microbial communities to metal contamination. Science of the Total Environment 408 (24): 6134 -6141. - doi: 10.1016/j.scitotenv.2010.08.056 Tarkalson DD, Payero JO, Hergert GW, Cassman $K G$ (2006). Acidification of soil in a dry land winter wheat-sorghum/corn-fallow rotation in the semiarid US great plains. Plant and Soil 283 (1): 367-379. - doi: 10.1007/s11104-006-0027-y Thomas RQ, Canham CD, Weathers KC, Goodale $C L$ (2010). Increased tree carbon storage in response to nitrogen deposition in the US. Nature Geoscience 3 (1): 229-244. - doi: 10.1038/n geo721

Tian D, Li P, Fang W, Xu J, Luo Y, Yan ZB, Zhu B, Wang JJ, Xu XN, Fang JY (2016). Contrasting growth responses among plant growth forms to nitrogen fertilization in a subtropical forest in China. Biogeosciences 14 (14): 1-19. - doi: 10.5194/bg-2016-416

Tian D, Jiang L, Ma S, Fang $W$, Schmid $B, X u L$, Zhu J, Li P, Losapio G, Jing X, Zheng C, Shen H,
Xu X, Zhu B, Fang J (2017). Effects of nitrogen deposition on soil microbial communities in temperate and subtropical forests in China. Science of the Total Environment 607-608: 13671375. - doi: 10.1016/j.scitotenv.2017.06.057

Tian D, Niu S (2015). A global analysis of soil acidification caused by nitrogen addition. Environmental Research Letters 10 (2): 024019. - doi: 10.1088/1748-9326/10/2/024019

Vitousek PM, Porder S, Houlton BZ, Chadwick OA (2010). Terrestrial phosphorus limitation: mechanisms, implications, and nitrogen-phosphorus interactions. Ecological Applications 20 (1): 5-15. - doi: 10.1890/08-0127.1

Wang R, Balkanski Y, Boucher O, Ciais P, Peñuelas J, Tao S (2015). Significant contribution of combustion-related emissions to the atmospheric phosphorus budget. Nature Geoscience 8: 48-54. - doi: 10.1038/ngeo2324

$\mathrm{Wu} \mathrm{J}$, Joergensen RG, Pommerening $B$, Chaussod R, Brookes PC (1990). Measurement of soil microbial biomass $C$ by fumigation-extractionan automated procedure. Soil Biology and Biochemistry 22 (8): 1167-1169. - doi: 10.1016/00380717(90)90046-3

Zhang X, Li D, Yang Y, Tang YQ, Wang HM, Chen FS, Sun XM (2016). Phosphorus applications improved the soil microbial responses under nitrogen additions in Chinese fir plantations of subtropical China. EGU General Assembly Conference, EGU General Assembly Conference Abstracts, Web site. [online] URL: http://adsa bs.harvard.edu/abs/2016EGUGA..18.5405Z

Zhang Y, Cong J, Lu H, Li G, Qu Y, Su X, Zhou J, Li D (2014). Community structure and elevational diversity patterns of soil Acidobacteria. Journal of Environmental Sciences 26 (8): 1717-1724. doi: 10.1016/j.jes.2014.06.012

Zheng BX, Hao XL, Ding K, Zhou GW, Chen QL, Zhang JB, Zhu YG (2017). Long-term nitrogen fertilization decreased the abundance of inorganic phosphate solubilizing bacteria in an alkaline soil. Scientific Reports 7: 42284. - doi: 10.103 8/srep42284

\section{Supplementary Material}

Tab. S1 - Effects of $\mathrm{N}$ and $\mathrm{P}$ additions on soil physiochemical properties in the secondary subtropical Castanopsis sclerophylla forest.

Tab. S2 - Outcome of the GLMMs model on the effect of $\mathrm{N}, \mathrm{P}$ additions, interaction effect and interactive treatment:block effects on soil bacterial diversity indexes.

Tab. S3 $_{3}$ - Outcome of the GLMMs model on the effect of $\mathrm{N}$ and $\mathrm{P}$ additions on the phylum-level OTUs of soil bacteria.

Tab. S4 - The most abundant OTUs at phylum and genus level with significant differences in treatments.

Tab. S5 - Monte Carlo permutation tests of the impact of soil chemical properties on the bacterial populations based on the OTUs

Link:Teng_2673@supploo1.pdf 